\title{
Integrated Determination of Chemical Oxygen Demand and Biochemical Oxygen Demand
}

\author{
Mengmeng Qi ${ }^{1,2}$, Yanhe Han ${ }^{1 *}$, Zikun Zhao ${ }^{1}$, Yang $\mathbf{L i}^{3}$ \\ ${ }^{1}$ Department of Environmental Engineering, Beijing Institute of Petrochemical Technology, Beijing, China \\ ${ }^{2}$ College of Environmental and Energy Engineering, Beijing University of Technology, Beijing, China \\ ${ }^{3}$ Beijing Changzheng Mechanical Equipment Manufacture Co. Ltd, Beijing, China
}

Received: 10 February 2020

Accepted: 14 May 2020

\begin{abstract}
Chemical oxygen demand (COD) and biochemical oxygen demand (BOD) with irreplaceable significance are comprehensive indicators for evaluating water quality. Effective control of water pollution depends on the rapid determination of these indicators. In the study, the rapid determination of BOD was carried out by activated sludge aeration degradation method. The BOD quantification was achieved by measuring the $\mathrm{COD}$ change before and after microbial degradation $\left(\mathrm{BOD}_{\triangle \mathrm{COD}}\right)$. Singlefactor experiment was employed to investigate the effect of operating parameters on the determination of BOD. In addition, the interactions of main variables were evaluated by Box-Behnken Design, and the results showed that the interaction term of reaction time and initial $\mathrm{pH}$ value had a significant effect. The optimum conditions for determination of BOD were reaction time of $273.68 \mathrm{~min}$, dosage of activated sludge of $8.72 \mathrm{~mL}$, and $\mathrm{pH}$ of 7.18 . Under the optimal conditions, the correlation experiment showed that $\mathrm{BOD}_{\triangle \mathrm{COD}}$ and $\mathrm{BOD}_{5}$ exhibited a good linear relationship in the concentration range of $0-500 \mathrm{mg} / \mathrm{L}$, and the correlation coefficient $\mathrm{R}^{2}$ was 0.996 . It indicated that the method realized not only the rapid determination of $\mathrm{BOD}$, but also the integrated determination of $\mathrm{COD}$ and BOD.
\end{abstract}

Keywords: integrated determination, activated sludge, chemical oxygen demand, biochemical oxygen demand, Box-Behnken Design

\section{Introduction}

Biochemical Oxygen Demand (BOD) was developed in the 18th century by the U.K. Royal Commission on River Pollution [1]. It is an important indicator to reflect the degree of organic pollution in wastewater and widely used in water quality monitoring, pollution control

*e-mail: hanyanhe@126.com and water management. The higher the BOD value is, the more serious the pollution is. At present, the main determination method is the 5-day biochemical oxygen demand $\left(\mathrm{BOD}_{5}\right)$, which is estimated by determining the amount of oxygen required for aerobic microorganisms to degrade organic matter in wastewater at a constant temperature of $20^{\circ} \mathrm{C}$ for 5 days. It was adopted as standardized method by American Public Health Association in 1936, and nowadays, has become an internationally established analytical method. However, the method shows some limitations: time-consuming 
[2], tedious procedures, more interference factors, and not suitable for real-time online monitoring. As a result, it is hardly to timely feedback the monitoring data of water, and to detect, warn and effectively control the pollution of the wastewater as early as possible.

Hence, as an alternative, several new methods for BOD determination have been developed to circumvent the disadvantages of standardized method. Manometric method was reported by Caldwell and Langelier in 1948 [3], which is based on the measurement of pressure decrease due to the oxygen consumption when microorganisms degrade the organic matters. The changes in pressure are measured by a manometer and converted to oxygen consumption by the device to estimate the BOD value. Comparing with the standardized method, the analytical procedure of this method is more simplified. However, it still requires $5 \mathrm{~d}$ measurement time. To reduce the analysis time, the first BOD biosensor was constructed by Karube in 1977 [4], consisting of a synthetic membrane with immobilized microorganisms as the biological recognition element and dissolved oxygen electrode. The method technically realizes the rapid determination of BOD (measurement time varies from several minutes to several hours), but it has some deficiencies in practical application, mainly including low efficiency and high selectivity due to single species of immobilized microorganisms, and complex immobilization method. Thus, considerable effort has been devoted to developing biofilm constructed with mixed microorganisms [5, 6] or activated sludge [7], and various immobilization methods [8-10] to circumvent the limitations. It has made great progress in these studies and many optimized BOD biosensors have been structured. However, present BOD biosensors basically adopt the variable quantity of dissolved oxygen as quantitative basis. And the consumption of dissolved oxygen tends to make biodegradable organic matter difficult to completely degrade, affecting the measurement results. In addition, the dissolved oxygen electrode needs to be periodically cleaned and replaced. To some extent, BOD biosensor is limited in application.

To eliminate the oxygen limitation in the biodegradation reaction, BOD biosensors based on the microbial fuel cell (MFC) are studied. MFC is a device that can directly convert the chemical energy of biodegradable organic matters to electrical energy through the catalytic activity of special electrochemically active microorganisms [11]. The electrical signal generated by microbial degradation of organic matters has a good linear relationship with the concentration of the organic matters, allowing the BOD value to be estimated [12]. On this basis, several types of MFC-based BOD sensors have been widely employed. It can be divided into two-chamber MFC and single-chamber MFC, according to the structure. Recently, most of studies use two-chamber MFC as sensor for BOD determination on account of its high stability and high efficiency. Nevertheless, the two-chamber MFC-type sensor has some weakness such as the complicated structure, requiring aeration to improve the efficiency of the cathode reaction, and expensive proton exchange membrane. To solve these issues, a single-chamber MFC-type sensor is developed, that provides some advantages for instance more compact and simple, neither aeration, nor proton exchange membrane $[13,14]$. However, single-chamber MFC- type sensor also has two challenges. One is that its coulombic efficiency is much lower than that of two-chamber MFC-type sensor owing to the consumption of organic matters by oxygen diffused to the anode [15]. The other is that oxygen may have a negative impact on the activity of the anaerobic microorganisms on the anode [16]. In addition, the electrons generated in the anode chamber need to pass through the membrane of electrochemically active bacteria to reach the anode, indicating that the thickness of the membrane directly affects the electron transfer efficiency. When the organic matters are degraded, the thickness of the membrane of electrochemically active bacteria will increase owing to proliferation, which limits the efficiency of electron transport. Moreover, some microbial cells are electrochemically inert. Consequently, mediators are added to facilitate electron transfer from the microbial cells to the electrode. Yet the mediators are generally toxic to microorganisms [17], resulting in a short-term stability, which is not conducive to the rapid detection of BOD. More importantly, the microorganisms involved in the oxidation reaction are mainly anaerobic microorganisms, leading the degradation of some oxygen-consuming pollutants cannot be completed. It indicates that MFC-type sensor has some technical defects. In summary, although the new methods have made great progress, there are still some limitations in practical application, and the determination of BOD cannot completely replace the standardized method.

By contrast, Chemical Oxygen Demand (COD) can overcome the shortcomings of BOD, that is defined as the amount of oxygen consumed when organic matter in water is degraded into small molecules by external powerful oxidant under certain conditions [18]. The standard method for determining COD is simple and fast, and the analysis time is greatly short by only 2 hours, compared with BOD [19]. Furthermore, some new approaches (e.g., ozone oxidation [20], electrocatalytic oxidation [21], photo-catalytic oxidation $[22,23]$ and photo-electrocatalytic oxidation [24-27] methods based on advanced oxidation processes) have been established with the innovative development of technology. And they are less time-consuming, environment friendly, and more reliable. However, the concept of COD has certain limitations obviously, such as not directly evaluating the biodegradable performance of water, and secondary pollution may be introduced during the determination process. Therefore, both BOD and COD have irreplaceable significance in the field of water quality monitoring [28]. In order 
Table 1. Characteristics of the simulated wastewater.

\begin{tabular}{|c|c|c|c|c|}
\hline Compositions & $\mathrm{COD}(\mathrm{mg} / \mathrm{L})$ & $\mathrm{NH}_{4}^{+}-\mathrm{N}(\mathrm{mg} / \mathrm{L})$ & $\mathrm{PO}_{4}{ }^{3-}-\mathrm{P}(\mathrm{mg} / \mathrm{L})$ & $\mathrm{pH}$ \\
\hline Concentrations & 250 & 12.5 & 2.5 & $\sim 7$ \\
\hline
\end{tabular}

to obtain accurate and comprehensive data in time, the rapid detection method of multi-indicator integration has become a research trend in the future. There have some studies to develop a rapid detection method of BOD, which obtains by the difference of COD before and after microbial degradation [29, 30]. As is wellknown, the initial COD value represents the amount of total organic matters including biodegradable and non-biodegradable ones. For a given sample, the COD value after biodegradation indicates only the amount of the non-biodegradable organic matters. Therefore, it is obvious that the difference of COD before and after microbial degradation $\left(\mathrm{BOD}_{\triangle \mathrm{COD}}\right)$ equals to the BOD value, because both represent the amount of biodegradable organic matters. The determination of BOD is transformed into the determination of COD that is simpler and faster, which not only achieves the purpose of rapid detection of $\mathrm{BOD}$, but also realizes the integrated detection of COD and BOD.

Based on the principle, the simultaneous determination of COD and BOD was developed by activated sludge aeration degradation method in this study. The organic matters in wastewater were degraded at a short time by the microorganisms in activated sludge. The BOD values were quantified by determining the $\mathrm{BOD}_{\triangle \mathrm{COD}}$ with potassium dichromate digestion method. Furthermore, the detection conditions of the method were explored and optimized by using single factor experiment and the response surface methodology.

\section{Experimental}

\section{Pretreatment of Activated Sludge}

Firstly, a centrifuge tube containing a certain amount of activated sludge was placed in the centrifuge and kept on centrifuging at $4000 \mathrm{r} / \mathrm{min}$ for $3 \mathrm{~min}$. The activated sludge was taken from a garbage treatment plant in Beijing. Then activated sludge was added again after removing the supernatant until the sludge was cleaned washed with deionized water. The cleaned sludge was cultured in a beaker at room temperature until formation of flocculent sludge was observed. The parameters of cultivated activated sludge were as follows: $\mathrm{SV}=22 \%, \mathrm{MLSS}=2.3 \mathrm{~g} / \mathrm{L}, \mathrm{SVI}=96 \mathrm{~mL} / \mathrm{g}$. Of course, the characteristics of activated sludge need to be maintained in a certain range ( $\mathrm{SV}=20 \sim 30 \%$, MLSS $=2 \sim 4 \mathrm{~g} / \mathrm{L} \mathrm{SVI}=50 \sim 150 \mathrm{~mL} / \mathrm{g}$ ) to ensure a strong biological activity.

The culturing completed sludge was washed again according to the above steps. Furthermore, the supernatant after centrifugation was scanned at wavelengths of $200-800 \mathrm{~nm}$ by ultraviolet spectrophotometer. When the absorption line of the last two supernatants was approaching, it indicated that the sludge had been cleaned.

\section{Experimental Method}

A $200 \mathrm{~mL}$ simulated wastewater (the compositions are shown in Table 1) was degraded in BOD degradation tank (Fig. 1) with the activated sludge at certain conditions. Furthermore, $3 \mathrm{~mL}$ inorganic nutrient solution which contained $\mathrm{MgSO}_{4}(22.5 \mathrm{~g} / \mathrm{L})$, $\mathrm{FeCl}_{3} \cdot 3 \mathrm{H}_{2} \mathrm{O}(0.25 \mathrm{~g} / \mathrm{L}), \mathrm{CaCl}_{2} \cdot 2 \mathrm{H}_{2} \mathrm{O}(27.5 \mathrm{~g} / \mathrm{L})$ was added for the growth of microorganisms in the activated sludge. During the reaction, the dissolved oxygen concentration was maintained at $3-5 \mathrm{mg} / \mathrm{L}$. After the reaction, $3 \mathrm{~mL}$ of the filtered wastewater was taken for the determination of COD. The obtained $\mathrm{BOD}_{\triangle \mathrm{COD}}$ caused by the biodegradation was used to quantify the BOD value of the sample. To optimize the operation conditions, a series of single factor experiments were performed using different reaction times, dosage of activated sludge, initial $\mathrm{pH}$ values, and reaction temperature.

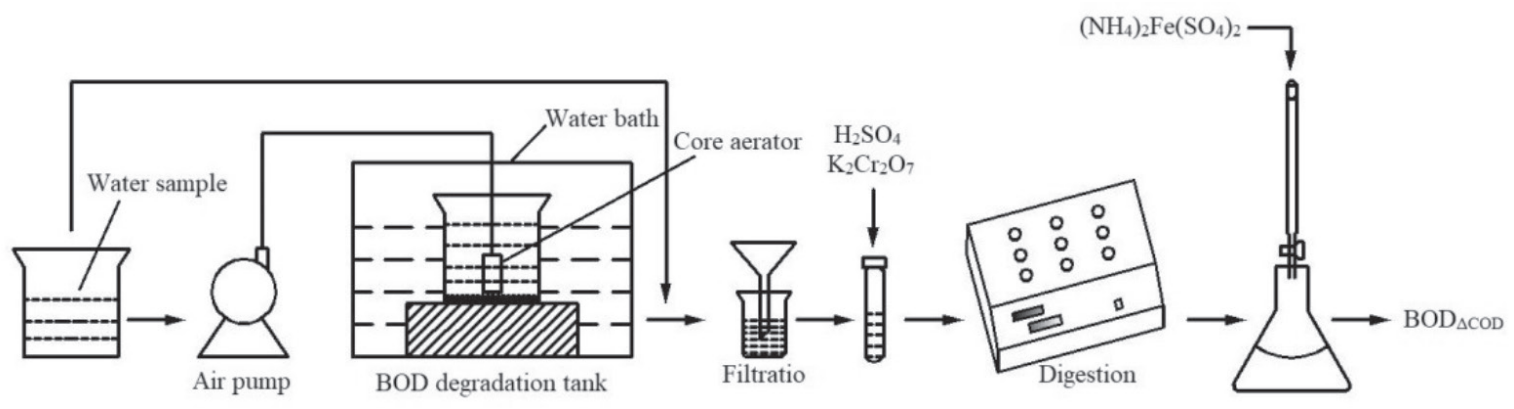

Fig. 1. Experimental device and process diagram. 


\section{Determination of COD and $\mathrm{BOD}_{5}$}

The potassium dichromate digestion method (standard method) was adopted for the determination of COD. The experiment was described that $3.0 \mathrm{~mL}$ of simulated wastewater was added to the digestion tube firstly, followed by the appropriate amount of masking agent, $\mathrm{K}_{2} \mathrm{Cr}_{2} \mathrm{O}_{7}$ digestion solution and catalyst, then digested in the digestion device for $15 \mathrm{~min}$. Finally, the COD value of wastewater sample was obtained according to the amount of $\left(\mathrm{NH}_{4}\right)_{2} \mathrm{Fe}\left(\mathrm{SO}_{4}\right)_{2}$ solution titrated. $\mathrm{BOD}_{5}$ was determined by conventional manometric method. The OxiToPIS6 BOD measurement system equipped with a pressure sensor was placed in a biochemical incubator maintained at $20^{\circ} \mathrm{C}$ for 5 days in the presence of simulated wastewater and nitrification inhibitor. All chemicals used in this study were of analytical reagent grade and all solutions were prepared using high-purity deionized water.

\section{Response Surface Experiment Design}

A Box-Behnken Design in response surface methodology was employed to analyze the interactive effect of these parameters and obtain optimal parameters, based on the results of single factor experiments. The results were analyzed on a PC running under Windows OS, using Design expert statistical software. The main variables were reaction time $\left(\mathrm{X}_{1}\right)$, dosage of activated sludge $\left(\mathrm{X}_{2}\right)$, and initial $\mathrm{pH}$ value $\left(\mathrm{X}_{3}\right)$. The dependent variables (response) were the $\mathrm{BOD}_{\triangle \mathrm{COD}}$ value. The experimental parameters and levels were shown in Table 2.

\section{Results and Discussion}

\section{Operational Conditions}

\section{Reaction Time}

The effect of reaction time on the degradation process of activated sludge was investigated while other parameters remained fixed. Fig. 2 showed the changes in $\mathrm{BOD}_{\triangle \mathrm{COD}}$ for simulated wastewater with glucose and glutamic acid over time. It describes that the $\mathrm{BOD}_{\triangle \mathrm{COD}}$ values for both simulated wastewaters generally have an increasing tendency, and tend to be constant after $240 \mathrm{~min}$. The $\mathrm{BOD}_{\triangle \mathrm{COD}}$ value increased significantly

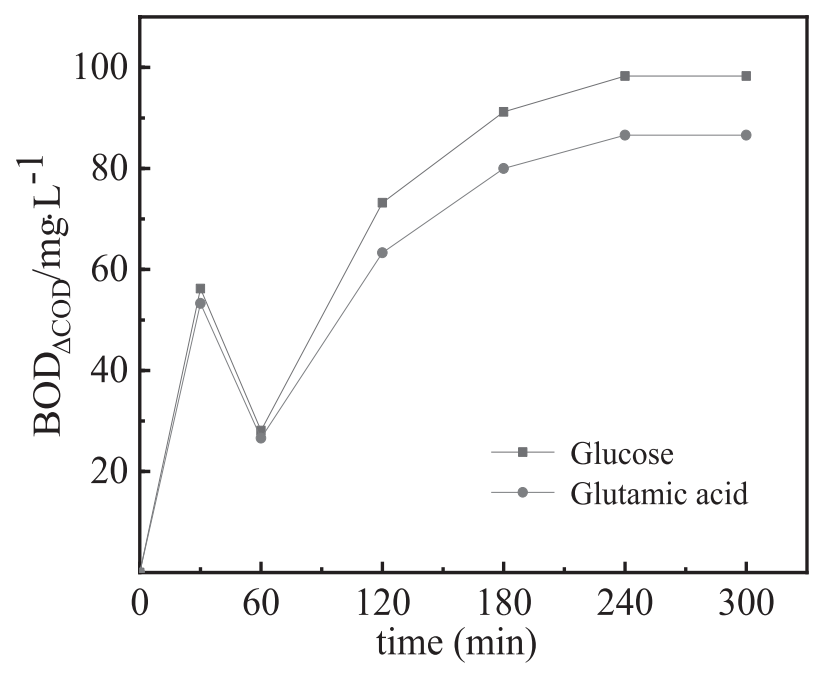

Fig. 2. Effect of degradation time on the $\mathrm{BOD}_{\triangle \mathrm{COD}}$ value (dosage of activated sludge $8 \mathrm{~mL}$; initial $\mathrm{pH} \mathrm{7}$; reaction temperature $\left.20^{\circ} \mathrm{C}\right)$.

within the reaction time of $30 \mathrm{~min}$. The reason may be that the activated sludge with a large specific surface area has good adsorption capacity for organic matters at the initial stage of the reaction. It made the COD after the reaction decrease rapidly, as a result, the increasing trend of the $\mathrm{BOD}_{\triangle \mathrm{COD}}$ value reached maximum. At the reaction time of $60 \mathrm{~min}$, the $\mathrm{BOD}_{\triangle \mathrm{COD}}$ value slightly decreased owing to the organic matters adsorbed on surface of the activated sludge were decomposed into small soluble molecular organic substances that reintroduction into wastewater. Due to the easy degradation of small molecular organic substances, the $\mathrm{BOD}_{\triangle \mathrm{COD}}$ value was significantly increased again within 60-180 min. After $180 \mathrm{~min}$, the change of the $\mathrm{BOD}_{\triangle \mathrm{COD}}$ value tended to be stable, and basically achieved constant at $240 \mathrm{~min}$. At this moment, the degradation of organic matters by activated sludge reached a relatively stable state. In addition, it can be seen from the figure that the two simulated wastewaters had different degrees of degradation. The biodegradation of organic matters is related to their molecular weight, spatial structure and types and quantities of substituents. Generally, the simpler the organic matters, the easier they are to be degraded. Therefore, glucose and glutamic acid with different physical characteristics and degree of biodegradability that determine their removal potential in a wastewater treatment system [31]. Therefore, to

Table 2. Level and code of experimental variables based on response surface methodology.

\begin{tabular}{|c|c|c|c|c|}
\hline Code & Factor & $\begin{array}{c}\text { Low levels } \\
(-1)\end{array}$ & $\begin{array}{c}\text { Medium levels } \\
(0)\end{array}$ & $\begin{array}{c}\text { High levels } \\
(+1)\end{array}$ \\
\hline $\mathrm{X}_{1}$ & Reaction time/(min) & 120 & 240 & 360 \\
\hline $\mathrm{X}_{2}$ & Dosage of activated sludge/(mL) & 6 & 8 & 10 \\
\hline $\mathrm{X}_{3}$ & $\mathrm{pH}$ & 6 & 7 & 8 \\
\hline
\end{tabular}




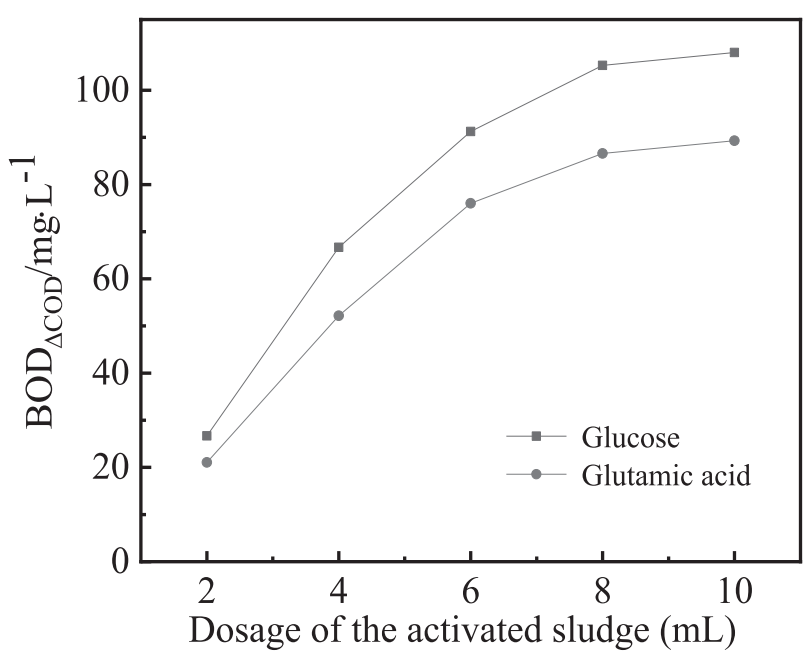

Fig. 3. Effect of dosage of activated sludge on the $\mathrm{BOD}_{\triangle \mathrm{COD}}$ value (degradation time $240 \mathrm{~min}$; initial $\mathrm{pH} \mathrm{7}$; reaction temperature $20^{\circ} \mathrm{C}$ ).

ensure a high degradation of organic pollutants, the reaction time was set to $240 \mathrm{~min}$ in further experiments.

\section{Dosage of Activated Sludge}

Fig. 3 depicted the varying for $\mathrm{BOD}_{\triangle \mathrm{COD}}$ at the activated sludge dosage values of $2,4,6,8,10 \mathrm{~mL}$. The result revealed that the $\mathrm{BOD}_{\triangle \mathrm{COD}}$ value increased with the increasing of dosage of activated sludge, especially when dosage of activated sludge was raised from 2 to 6 $\mathrm{mL}$, the $\mathrm{BOD}_{\triangle \mathrm{COD}}$ value increased almost linearly. The trend can be attributed to the fact that the amount of biodegradable organic matters in simulated wastewater was much larger than that can be degraded by activated sludge. At this stage, dosage of activated sludge was the controlling factor of degradation reaction. When dosage of sludge increased from $6 \mathrm{~mL}$ to $10 \mathrm{~mL}$, the increasing of the $\mathrm{BOD}_{\triangle \mathrm{COD}}$ value gradually slowed down. The main reason was that the amount of organic matters which can be degraded by activated sludge was close to the one of biodegradable organic matters in simulated wastewater. Dosage of activated sludge was no longer the main controlling factor of degradation reaction. The removal rate will not increase any more, even if the activated sludge was continued to add. Therefore, dosage of activated sludge was set at $8 \mathrm{~mL}$ in the subsequent experiments.

\section{Initial pH Value}

The activities of activated sludge are highly dependent on the environments where microorganisms are living, such as $\mathrm{pH}$ value [5]. Hence, experiments based on various $\mathrm{pH}$ values (5.0-9.0) had been carried out when other operation parameters were fixed. As shown in Fig. 4, the highest $\mathrm{BOD}_{\triangle \mathrm{COD}}$ value emerged at $\mathrm{pH}$ 7. It indicated that the microorganisms of activated sludge had the highest degradation at $\mathrm{pH}$ 7. Meanwhile,

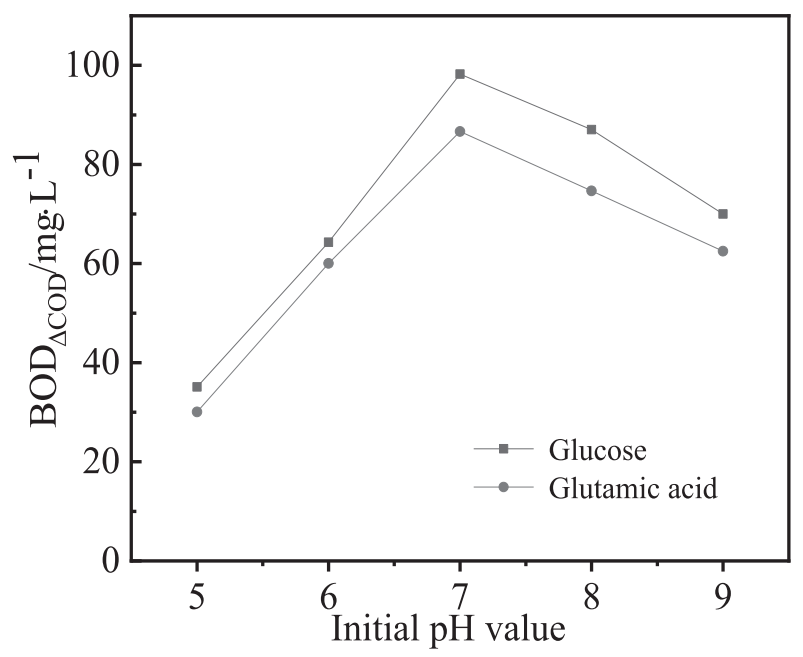

Fig. 4. Effect of initial $\mathrm{pH}$ value on the $\mathrm{BOD}_{\triangle \mathrm{COD}}$ value (degradation time $240 \mathrm{~min}$; dosage of activated sludge $8 \mathrm{~mL}$; reaction temperature $20^{\circ} \mathrm{C}$ ).

the $\mathrm{BOD}_{\triangle \mathrm{COD}}$ value whether it occurred under acidic or alkaline environments was lower than that at $\mathrm{pH} 7$, indicating that the activities of activated sludge were inhibited. In conclusion, the $\mathrm{pH}$ was kept at 7 during the following experiments.

\section{Reaction Temperature}

The effect of the reaction temperature was evaluated on the degradation of activated sludge as shown in Fig. 5. The $\mathrm{BOD}_{\triangle \mathrm{COD}}$ value increased sharply when the temperature was raised from 10 to $20^{\circ} \mathrm{C}$ and reached the maximum in the temperature range of $20-30^{\circ} \mathrm{C}$. When the temperature was further increased to $30-50^{\circ} \mathrm{C}$, the $\mathrm{BOD}_{\triangle \mathrm{COD}}$ value decreased gradually. It is well known that microorganisms in activated

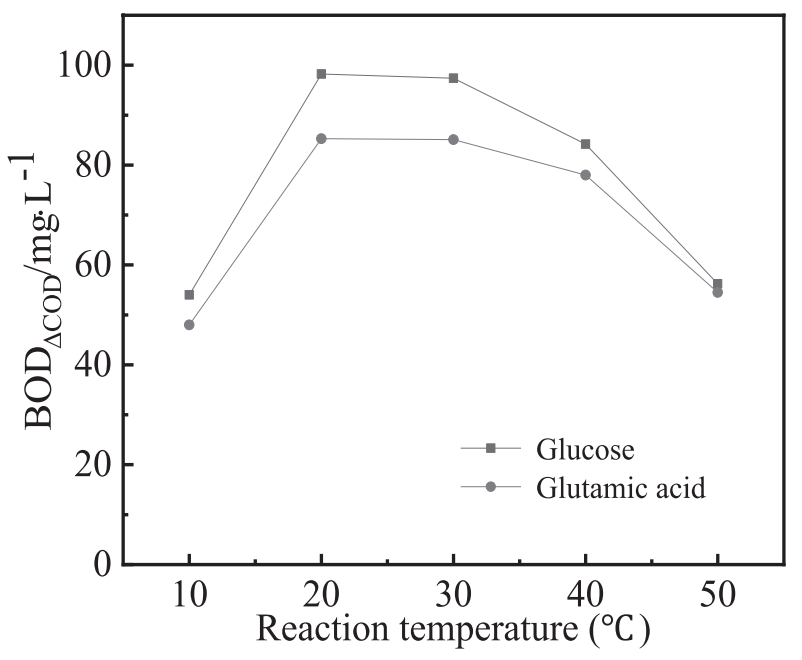

Fig. 5. Effect of reaction temperature on the $\mathrm{BOD}_{\triangle \mathrm{COD}}$ value (degradation time $240 \mathrm{~min}$; dosage of activated sludge $8 \mathrm{~mL}$; initial $\mathrm{pH}$ 7). 
sludge generally have an optimum temperature range $\left(15-35^{\circ} \mathrm{C}\right)$. It will affect the activity of microorganisms whether in too high or too low temperature [32]. When the temperature is too high, those temperature-sensitive constituent materials such as proteins and nucleic acids may suffer irreversible damage, resulting in a decrease in the metabolic activity of the microorganisms and the degradation ability. When the temperature is too low, the growth rate of the microorganism and the rate of the biochemical reaction are suppressed, although the structure of the microorganisms can't be destroyed. Considering that high temperature will lead to high energy consumption, $20^{\circ} \mathrm{C}$ was chosen as optimal temperature under the conditions explored in this study.

\section{Optimization Using Response Surface Methodology}

\section{Model Establishment}

The results obtained from single factor experiment showed that reaction time, dosage of activated sludge and initial $\mathrm{pH}$ value had an important influence on the degradation of activated sludge. However, the single factor experiment has certain limitations due to not considering the possible interaction between parameters. In order to overcome this problem, multivariate statistic techniques especially response surface methodology

Table 3. The design and results of experiments by Box-Behnken Design.

\begin{tabular}{|c|c|c|c|c|}
\hline Number & $\mathrm{X}_{1}$ & $\mathrm{X}_{2}$ & $\mathrm{X}_{3}$ & $\begin{array}{c}\text { The difference } \\
\text { of COD/(mg/L) }\end{array}$ \\
\hline 1 & 0 & +1 & +1 & 138.40 \\
\hline 2 & +1 & 0 & -1 & 99.67 \\
\hline 3 & 0 & -1 & -1 & 86.24 \\
\hline 4 & 0 & -1 & +1 & 116.87 \\
\hline 5 & 0 & 0 & 0 & 168.75 \\
\hline 6 & +1 & -1 & 0 & 131.92 \\
\hline 7 & 0 & 0 & 0 & 169.20 \\
\hline 8 & 0 & 0 & 0 & 168.10 \\
\hline 9 & +1 & 0 & +1 & 136.07 \\
\hline 10 & 0 & +1 & -1 & 102.13 \\
\hline 11 & -1 & +1 & 0 & 116.45 \\
\hline 12 & -1 & -1 & 0 & 98.34 \\
\hline 13 & -1 & 0 & +1 & 100.68 \\
\hline 14 & 0 & 0 & 0 & 168.00 \\
\hline 15 & 0 & 0 & 0 & 163 \\
\hline 16 & +1 & +1 & 0 & 156.22 \\
\hline 17 & -1 & 0 & -1 & 84.30 \\
\hline
\end{tabular}

had been put forward [33]. Hence, the experiment was further analyzed and optimized by Box-Behnken Design for determining the optimal process parameters in this study. The design and results of experiment carried out by the Box-Behnken Design were given in Table 3.

The multiple regression analysis on the resulted response led to the following second-order polynomial equation which explained the relation and interactions of response (the $\mathrm{BOD}_{\triangle \mathrm{COD}}$ value) with significant factors:

$$
\begin{gathered}
Y=167.41+15.51 X_{1}+9.98 X_{2}+14.96 X_{3}+1.55 X_{1} X_{2}+ \\
5.00 X_{1} X_{3}+1.41 X_{2} X_{3}-23.70 X_{1}^{2}-17.97 X_{2}^{2}-38.53 X_{3}^{3}
\end{gathered}
$$

\section{Analysis of Variance and Significance Test}

In optimizing a response surface, it is important to ensure the adequacy of the employed model which was checked using the analysis of variances (ANOVA). Table 4 gave the analysis of variance (ANOVA) of the regression model. As it can be seen from the table, the model P-value of $<0.0001$ indicated the model was significant. There was only $0.01 \%$ chance that a model $F$ value could occur due to noise, which also confirmed the high significance of model. The result obtained by ANOVA implied that lack of fit was not significant because the P-value of 0.0808 was lower than 0.05 , and regression was meaningful. The value of correlation coefficient R2 of 0.9830 , suggested that only $1.7 \%$ of the total variation could not be explained by the model. Goodness-of-fit for the model was also evaluated by the adjusted regression coefficient obtained in the present study, indicating a better correlation between the observed and predicted values. Hence, the response surface model proposed in this study was considered to have satisfactory representation.

Values of "Probability $>F$ " less than 0.0500 showed that model terms were significant [34]. In this case, the interaction between reaction time and initial $\mathrm{pH}$ value was found.

\section{Response Surface Interaction Analysis}

The response surface and contour plots of the above model as two factors varying within the experimental ranges while the others were kept constant were shown in Fig. 6. Usually the constant variable is chosen at its middle level (zero point). Not only the independent influence of factors but also the interaction between factors can be displayed, through visual inspection of the response surface and contour plots.

The effect of interaction of reaction time and dosage of activated sludge on the $\mathrm{BOD}_{\triangle \mathrm{COD}}$ value was illustrated in Fig. 6a). The contours were parallel to the two axes suggesting that there was not a significant interaction between the two parameters. Fig. 6b) showed a similar trend between dosage of activated sludge and initial $\mathrm{pH}$ value which indicated that the two parameters were quite independent of each other. 
Table 4. ANOVA results for the response surface quadratic model.

\begin{tabular}{|c|c|c|c|c|c|}
\hline Source & Sum of squares & DF & Mean square & F value & $\mathrm{p}$-Value \\
\hline Model & 15620.50 & 9 & 1735.61 & 103.76 & $<0.0001$ \\
\hline$X_{1}$ & 1925.41 & 1 & 1925.41 & 115.10 & $<0.0001$ \\
\hline $\mathrm{X}_{2}$ & 796.60 & 1 & 796.60 & 47.62 & 0.0002 \\
\hline$X_{3}$ & 790.41 & 1 & 1790.41 & 107.03 & $<0.0001$ \\
\hline $\mathrm{X}_{1} \mathrm{X}_{2}$ & 9.58 & 1 & 9.58 & 0.57 & 0.4739 \\
\hline $\mathrm{X}_{1} \mathrm{X}_{3}$ & 100.20 & 1 & 100.20 & 5.99 & 0.0443 \\
\hline $\mathrm{X}_{2} \mathrm{X}_{3}$ & 7.95 & 1 & 7.95 & 0.48 & 0.5127 \\
\hline $\mathrm{X}_{1}^{2}$ & 2365.76 & 1 & 2365.76 & 141.43 & $<0.0001$ \\
\hline $\mathrm{X}_{2}^{2}$ & 1360.23 & 1 & 1360.23 & 81.32 & $<0.0001$ \\
\hline $\mathrm{X}_{3}^{2}$ & 6249.57 & 1 & 6249.57 & 373.60 & $<0.0001$ \\
\hline Residual & 117.09 & 7 & 16.73 & & \\
\hline Lack of Fit & 91.82 & 3 & 30.61 & 4.84 & 0.0808 \\
\hline Pure error & 25.27 & 4 & 6.32 & & \\
\hline Total & 15737.60 & 16 & & & \\
\hline
\end{tabular}

To study the interaction effect of reaction time and initial $\mathrm{pH}$ value on the $\mathrm{BOD}_{\triangle \mathrm{COD}}$ value, the experiments were carried out with initial $\mathrm{pH}$ value varying from 6.0 to 8.0 and under different reaction times at constant dosage of activated sludge of $8 \mathrm{~mL}$. The result was given in Fig. 6c). It can be seen that the curved surface was higher in the middle and lower in the periphery. The $\mathrm{BOD}_{\triangle \mathrm{COD}}$ value attained the largest meaning best the degradation of activated sludge when reaction time was 200-360 min and $\mathrm{pH}$ was 6.8-7.8. It was attributed to the fact that the microorganisms in activated sludge are more active in a neutral or weakly alkaline
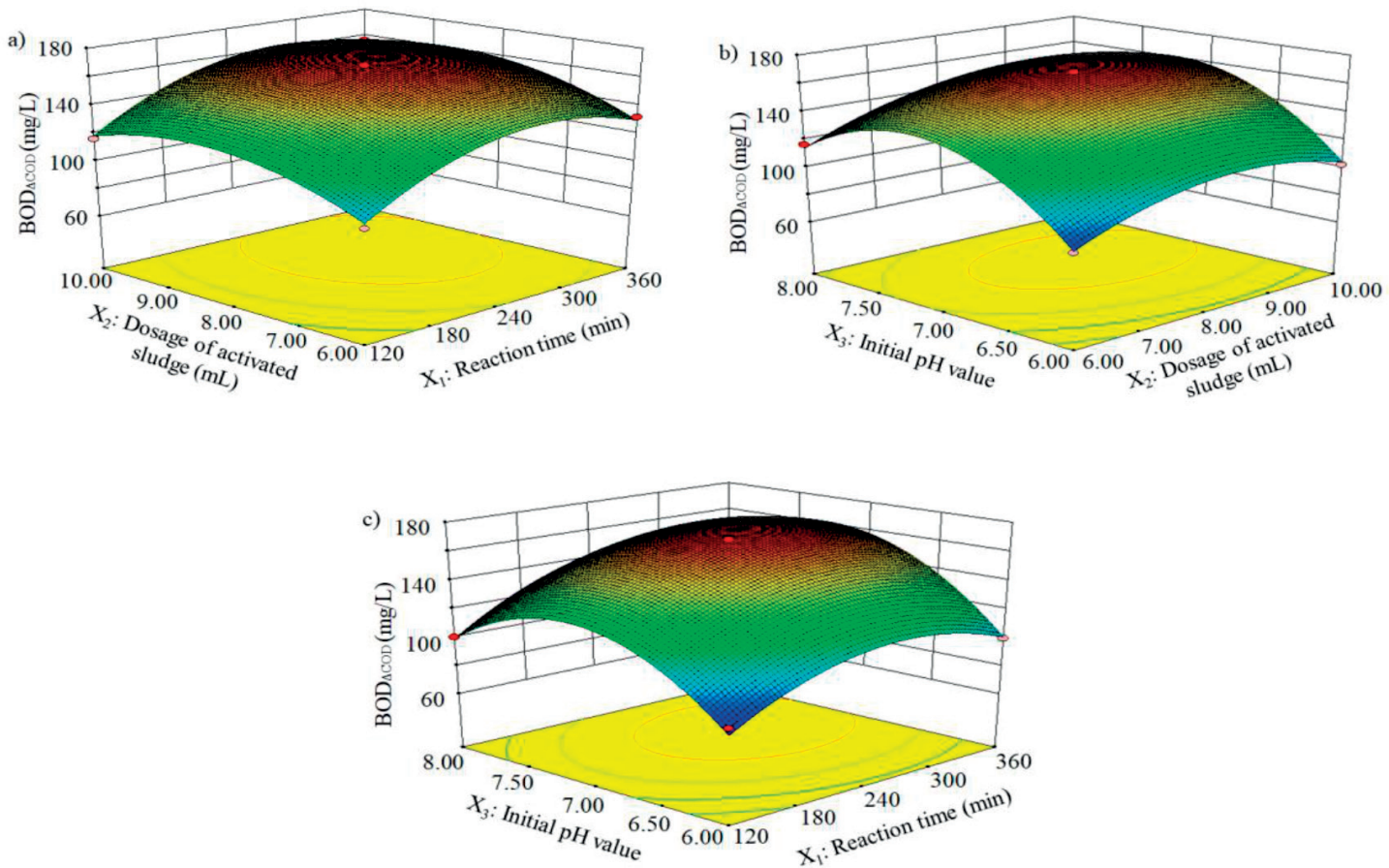

Fig. 6. Contour and response surface plots a) The interaction effect of reaction time and dosage of activated sludge on the $\mathrm{BOD}_{\triangle \mathrm{COD}} \mathrm{value}$ b) the interaction effect of dosage of activated sludge and initial $\mathrm{pH}$ value on the $\mathrm{BOD}_{\triangle \mathrm{COD}}$ value; and c) the interaction effect of reaction time and initial $\mathrm{pH}$ value on the $\mathrm{BOD}_{\triangle \mathrm{COD}}$ value. 


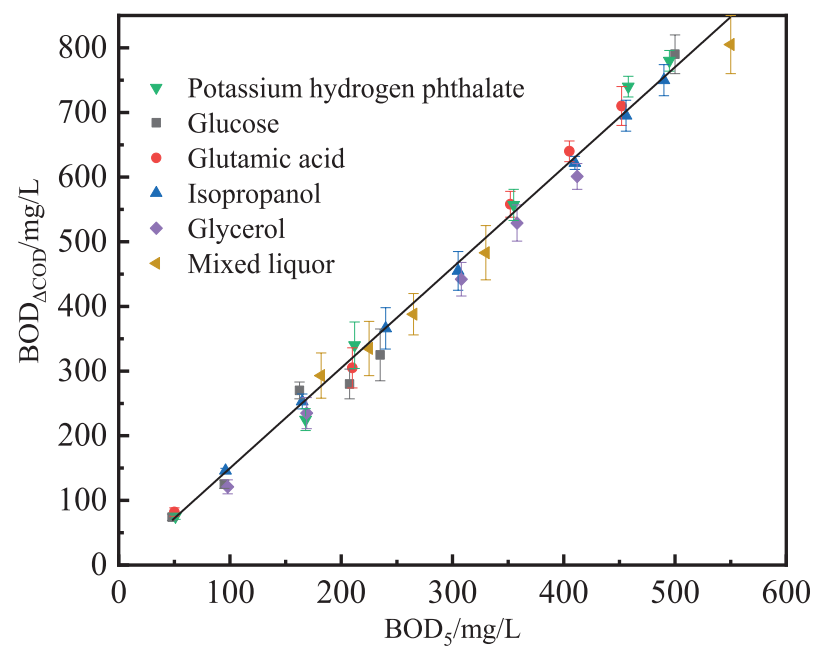

Fig. 7. Correlation between $\mathrm{BOD}_{\triangle \mathrm{COD}}$ by the activated sludge aeration degradation method and $\mathrm{BOD}_{5}$ by the conventional manometric method (degradation time $240 \mathrm{~min}$; dosage of activated sludge $8 \mathrm{~mL}$; initial $\mathrm{pH} \mathrm{7}$; reaction temperature $20^{\circ} \mathrm{C}$ ).

environment. The activity of the microorganisms will be inhibited at extreme conditions, whether acidic or alkaline. The intermediate substances produced during the degradation reaction may have an influence on the $\mathrm{pH}$ of wastewater, thereby affecting the reaction. As the development of reaction, the more complete the degradation achieved, the higher the $\mathrm{BOD}_{\triangle \mathrm{COD}}$ value was.

The optimal parameters were obtained by using the point prediction option in the software. It was found that reaction time, dosage of activated sludge and initial $\mathrm{pH}$ value were $273.68 \mathrm{~min}, 8.72 \mathrm{~mL}$ and 7.18 , respectively. For verifying the reliability of the model, repeated confirmatory experiments were performed using the optimized parameters. The result showed that the average of the $\mathrm{BOD}_{\triangle \mathrm{COD}}$ value was $160.54 \mathrm{mg} / \mathrm{L}$, which was within the $95 \%$ confidence interval for predicted value. Hence, the Box-Behnken Design incorporate with desirability functions could be effectively used to optimize the design for experiments on the degradation of activated sludge with high accuracy and reliability.

\section{Relationship between $\mathrm{BOD}_{\triangle \mathrm{COD}}$ and $\mathrm{BOD}_{5}$}

In order to investigate the feasibility of the activated sludge aeration degradation method for BOD determination, the $\mathrm{BOD}_{\triangle \mathrm{COD}}$ values of various simulated wastewater (including Potassium hydrogen phthalate, glucose, glutamic acid, isopropanol, glycerol, and their mixed liquor) were determined under the above optimized conditions, and compared with the corresponding BOD5 value determined by the conventional manometric method. The relationship between $\mathrm{BOD}_{\triangle \mathrm{COD}}$ and $\mathrm{BOD}_{5}$ was given in Fig. 7 and the regression equation was $\mathrm{y}=1.55 \mathrm{x}-5.17$. A highly significant correlation $(\mathrm{R}=0.996, \mathrm{n}=34)$ between the two methods indicates that the two methods have a good conformity. Furthermore, it can be seen that the detection limit of the method can be at least $500 \mathrm{mg} / \mathrm{L}$, due to $\mathrm{BOD}_{\triangle \mathrm{COD}}$ and $\mathrm{BOD}_{5}$ are linearly related in this range.

\section{Conclusions}

In summary, we have proposed and experimentally validated a novel BOD analytical system which is based on the difference of COD before and after microbial degradation. The reported system is not only capable of rapidly determining BOD of wastewaters without the need for dilution and ongoing calibration, but also able to realize integrated detection of COD and BOD. In this work, the optimal conditions for the BOD determination were investigated by single factor experiment and response surface methodology, obtaining reaction time of $273.68 \mathrm{~min}$, dosage of activated sludge of $8.72 \mathrm{~mL}$ and initial $\mathrm{pH}$ value of 7.18 .

The correlation experiment result showed that a high significant correlation between the two methods was obtained, and the linear range can reach $500 \mathrm{mg} / \mathrm{L}$. The method is promising for practical rapid BOD monitoring applications because of short-time analysis, little reagent consuming and minimal operational maintenance. Meanwhile, it provides a research basis for multi-index integrated detection technology. However, the BOD value obtained in this work mainly includes easily degradable, non-volatile and soluble BOD. The applicability of the proposed method for wastewaters containing complex and diversified biodegradable organic matters, especially for real wastewater was not studied. Hence, more in-depth researches still need to be developed.

\section{Acknowledgements}

This work was supported by the Joint Fund of the Beijing Municipal Natural Science Foundation and Beijing Municipal Education Commission (KZ201810017024), National Natural Science Foundation of China (21677018) and State Key Laboratory of Petroleum Pollution Control (PPC2017006).

\section{Conflict of Interest}

The authors declare no conflict of interest.

\section{References}

1. JOUANNEAU S., RECOULES L., DURAND M.J., BOUKABACHE A., PICOT V., PRIMAULT Y., LAKEL A., SENGELIN M., BARILLON B., THOUAND G. Methods for assessing biochemical oxygen demand (BOD): A review. Water Research, 49, 62, 2014. 
2. YAMASHITA T., OOKAWA N., ISHIDA M., KANAMORI H., SASAKI H., KATAYOSE Y., YOKOYAMA H. A novel open-type biosensor for the in-situ monitoring of biochemical oxygen demand in an aerobic environment. Scientific Reports, 6, 38552, 2016.

3. H. CALDWELL D., F. LANGELIER W. Manometric measurement of the biochemical oxygen demand of sewage. Sewage Works Journal, 20 (2), 202, 1948.

4. KARUBE I., MATSUNAGA T., MITSUDA S., SUZUKI S. Microbial electrode BOD sensors. Biotechnology and Bioengineering, 19 (10), 1535, 1977.

5. NIYOMDECHA S., LIMBUT W., NUMNUAM A., ASAWATRERATANAKUL P., KANATHARANA P., THAVARUNGKUL P. A novel BOD biosensor based on entrapped activated sludge in a porous chitosan-albumin cryogel incorporated with graphene and methylene blue. Sensors and Actuators B: Chemical, 241, 473, 2017.

6. LIU L., BAI L., YU D., ZHAI J., DONG S. Biochemical oxygen demand measurement by mediator method in flow system. Talanta, 138, 36, 2015.

7. JORDAN M.A., WELSH D.T., TEASDALE P.R. Ubiquity of activated sludge ferricyanide-mediated BOD methods: A comparison of sludge seeds across wastewater treatment plants. Talanta, 125, 293, 2014.

8. LI Y.J., SUN J.Z., WANG J.F., BIAN C., TONG J.H., LI Y., XIA S.H. A microbial electrode based on the co-electrodeposition of carboxyl graphene and $\mathrm{Au}$ nanoparticles for BOD rapid detection. Biochemical Engineering Journal, 123, 86, 2017.

9. HU J.F., LI Y.Q., GAO G.W., XIA S.H. A mediated BOD biosensor based on immobilized B. Subtilis on threedimensional porous graphene-polypyrrole composite. Sensors, 17 (11), 2594, 2017.

10. NIYOMDECHA S., LIMBUT W., NUMNUAM A., ASAWATRERATANAKUL P., KANATHARANA P., THAVARUNGKUL P. A novel BOD biosensor based on entrapped activated sludge in a porous chitosan-albumin cryogel incorporated with graphene and methylene blue. Sensors and Actuators B: Chemical, 241, 473, 2017.

11. SHEN Y.J., LEFEBVRE O., TAN Z., NG H.Y. Microbial fuel-cell-based toxicity sensor for fast monitoring of acidic toxicity. Water Science \& Technology, 65 (7), 1223, 2012.

12. SUN J.Z., PETER KINGORI G., SI R.W., ZHAI D.D., LIAO Z.H., SUN D.Z., ZHENG T., YONG Y.C. Microbial fuel cell-based biosensors for environmental monitoring: a review. Water Science \& Technology, 71 (6), 801, 2015.

13. YANG G.X., SUN Y.M., KONG X.Y., ZHEN F., LI Y., LI L.H., LEI T.Z., YUAN Z.H., CHEN G.Y. Factors affecting the performance of a single-chamber microbial fuel celltype biological oxygen demand sensor. Water Science \& Technology, 68 (9), 1914, 2013.

14. XIMENA C.A., NATALIA J.S., MARIA C.B., ASTRID H.O., EDUARDO C. Analytical applications of microbial fuel cells. Part I: Biochemical oxygen demand. Biosensors and Bioelectronics, 63, 580, 2015.

15. AYYARU S., DHARMALINGAM S. Enhanced response of microbial fuel cell using sulfonated poly ether ether ketone membrane as a biochemical oxygen demand sensor. Analytica Chimica Acta, 818, 15, 2014.

16. LIU H., CHENG S., LOGAN B.E. Power generation in fedbatch microbial fuel cells as a function of ionic strength, temperature, and reactor configuration. Environmental Science \& Technology, 39 (14), 5488, 2005.

17. HSIEH M.C., CHENG C.Y., LIU M.H., CHUNG Y.C. Effects of operating parameters on measurements of biochemical oxygen demand using a mediatorless microbial fuel cell biosensor. Sensors, 16 (1), 35, 2015.

18. GEERDINK R.B., SEBASTIAAN VAN DEN HURK R., EPEMA O.J. Chemical oxygen demand: Historical perspectives and future challenges. Analytica Chimica Acta, 961, 1, 2017.

19. MA J. Determination of chemical oxygen demand in aqueous samples with non-electrochemical methods. Trends in Environmental Analytical Chemistry, 14, 37, 2017.

20. PISUTPAISAL N., SIRISUKPOCA U. Development of rapid chemical oxygen demand analysis using ozone as oxidizing agent[J]. Energy Procedia, 50, 711, 2014.

21. MA C.J., TAN F., ZHAO H.M., CHEN S., QUAN X. Sensitive amperometric determination of chemical oxygen demand using $\mathrm{Ti} / \mathrm{Sb}-\mathrm{SnO}_{2} / \mathrm{PbO}_{2}$ composite electrode[J]. Sensors \& Actuators B: Chemical, 155 (1), 114, 2011.

22. WANG H., ZHONG S.H., HE Y., SONG G.W. Molecular sieve $4 \mathrm{~A}-\mathrm{TiO}_{2}-\mathrm{K}_{2} \mathrm{Cr}_{2} \mathrm{O}_{7}$ coexisted system as sensor for chemical oxygen demand[J]. Sensors \& Actuators B: Chemical, 160 (1), 189, 2011.

23. ZHANG Z.H., YUAN Y., FANG Y.J., LIANG L.H., DING H.C., JIN L.T. Preparation of photocatalytic nano- $\mathrm{ZnO} /$ $\mathrm{TiO}_{2}$ film and application for determination of chemical oxygen demand[J]. Talanta, 73 (3), 523, 2007.

24. WANG X.J., ZHANG S.S., WANG H J., YU H., WANG H.H., ZHANG S.Q, PENG F. Visible light photoelectrochemical properties of hydrogenated $\mathrm{TiO}_{2}$ nanorod film and its application in the detection of chemical oxygen demand[J]. RSC Advances, 5 (93), 76315, 2015.

25. HAN Y.H., QIU J.X., MIAO Y.Q., HAN J.S., ZHANG S.Q., ZHANG H.M., ZHAO H.J. Robust $\mathrm{TiO}_{2} / \mathrm{BDD}$ heterojunction photoanodes for determination of chemical oxygen demand in wastewaters[J]. Analytical Methods, 3 (9), 2003, 2011.

26. ZHANG S.Q., ZHAO H.J., JIANG D.L., JOHN R. Photoelectrochemical determination of chemical oxygen demand based on an exhaustive degradation model in a thin-layer cell[J]. Analytica Chimica Acta, 514 (1), 89, 2004.

27. ZHANG S.Q., LI L.H., ZHAO H.J. A portable miniature UV-LED-based photoelectrochemical system for determination of chemical oxygen demand in wastewater[J]. Sensors \& Actuators B: Chemical, 141 (2), 634, 2009.

28. SILVA A.M., SILVA R.J., CAMOES M.F. Optimization of the determination of chemical oxygen demand in wastewaters. Analytica Chimica Acta, 699 (2), 161, 2011.

29. HAN Y.H., CHEN J.Q., WANG P., RUAN X.L. Advances in on-line detecting technologies of chemical oxygen demand, biochemical oxygen demand and toxicity in water. Science \& Technology Review, 31 (36), 76, 2013.

30. LIU C., ZHAO H., MA Z., AN T., LIU C., ZHAO L., YONG D., JIA J., LI X., DONG S. Novel environmental analytical system based on combined biodegradation and photoelectrocatalytic detection principles for rapid determination of organic pollutants in wastewaters. Environmental Science \& Technology, 48 (3), 1762, 2014.

31. EKAMA G.A., WENTZEL M.C. Organic matter removal. In: Biological wastewater treatment: principles, modelling and design[M]. London, UK: IWA Publishing; 2008.

32. CHEN J.S., ZHANG L.S., WANG J. A novel biosensor for the rapid determination of biochemical oxygen 
demand. Biomedical and Environmental Sciences, 20, 78, 2007.

33. SOUMYA PANDIT, SOUPARNO GHOSH, GHANGREKAR M.M., DAS D. Performance of an anion exchange membrane in association with cathodic parameters in a dual chamber microbial fuel cell. International Journal of Hydrogen Energy, 37 (11), 9383, 2012.
34. AHMAD M.Z., EHTISHAM-UL-HAQUE S., NISAR N., QURESHI K., GHAFFAR A., ABBAS M., NISAR J., IQBAL M. Detoxification of photo-catalytically treated 2-chlorophenol: optimization through response surface methodology. Water Science \& Technology, 76 (2), 323, 2017. 